\title{
The Importance of Soft Skills for the Engineering
}

\section{Débora Barni de Campos, Luis Mauricio Martins de Resende, Alexandre Borges Fagundes}

North Plateau Education Center, State University of Santa Catarina, São Bento do Sul, SC, Brazil

Email: deborabarni@gmail.com

How to cite this paper: de Campos, D. B. de Resende, L. M. M., \& Fagundes, A. B. (2020). The Importance of Soft Skills for the Engineering. Creative Education, 11, 1504-1520.

https://doi.org/10.4236/ce.2020.118109

Received: December 18, 2019

Accepted: August 25, 2020

Published: August 28, 2020

Copyright $\odot 2020$ by author(s) and Scientific Research Publishing Inc. This work is licensed under the Creative Commons Attribution International License (CC BY 4.0).

http://creativecommons.org/licenses/by/4.0/

(c) (i) Open Access

\begin{abstract}
The objectives of this paper are to structure and discuss the main soft skills that have an impact on the employability in the Engineering field, aiming to fill the gap between education and job market in the STEM field. A systematized literature review (SLR) on Humanities and Engineering Education of 2638 articles showed that the most important soft skills for the employability of engineers can be grouped into six main groups: Problem Solving and Critical Thinking, Communication, Team Work, Ethical Perspective, Emotional Intelligence and Creative Thinking. The definition and relation between these skills and Engineering work are explored within the present work, concluding with a reflection about fresh graduate Engineers and their readiness for the job market.
\end{abstract}

\section{Keywords}

Engineering Education, Employability of the Engineer, Soft Skill for Engineering

\section{Introduction}

Human Sciences is the science that aims to understand and explain how the cultural, historic and political context plays a role in shaping human behavior, and help explain the apparent paradox of humans' behavior of being both unique individuals and social beings (Vasconcelos, 2018).

Socio-emotional skills, also known as soft skills, are related to those characteristics that one uses to relate to others, and that help to build their so-called social web (Itani \& Sprour, 2015). These skills are not only limited to relational characteristics, but also englobe other behaviors, such as Social Responsibility, Creativity, Ethics and Emotional Intelligence.

Driven by the globally connected economy, the labor market has shifted to 
emphasize and legitimize the importance of soft skills for employability mostly in all the careers.

Over the years, various US organizations such as the National Academy of Engineering (NAE) and the Accreditation Council for Engineering and Technology (ABET) have taken proactive steps to address and respond to the importance of soft skills in Engineering. However, from a broader perspective, still little effort has been conducted to connect the pieces and understand which soft skills have a stronger impact on each career or field, especially on those fields in STEM (Science, Technology, Engineering and Mathematics).

The NAE report addressed the technological, social and global contexts implications for engineering education and pointing out a set of desirable attributes in the future Engineer professionals. Although many of these attributes are similar to the ones required in the past and currently, the study highlights the greater complexity of them, due to the impact of new technology. Stronger analytical forces, creativity, communication, and high ethical standards are some of the skills listed in the report (Vasko, Al-Masoud, \& Baumann, 2011; Koen \& Kohli, 1998).

The lack of knowledge and organization on studies related to the importance of soft skills for STEM professionals is linked to the fact that these skills are usually taken for granted. It also reflects the low emphasis on the soft skills in the STEM education and the consequent egress panorama (Ríos Carmenado, López, \& García, 2015; Veiga, 2017; Pereira \& Costa, 2017).

To legitimize the Humanities in Engineering they need to be validated in the same way as Technology, using trustful sources to support it (Marrocu \& Paci, 2012).

This highlights the importance to structure the current state of the art about soft skills in the STEM field, as a way to connect the Academia and the market. In the present work, the main focus will be the Engineering field, given its good representative of the STEM field.

The main objective of this paper is to gather and present in a structured manner the current studies on soft skills for Engineering and to discuss not only how they relate to employability, but also on how they need to be developed and approached in the educational context to make fresh-graduate Engineers in line with the market's needs.

\section{Theoretical Framework}

\section{Employability of Engineers}

Employability is defined as a group of social and cultural evidences which serve as an indicator of economic and social development (Silva et al., 2019). The rapid transformation of the workplace to a more inclusive environment and a highly competitive labor market has changed the nature of employability today. In addition to the job-related technical knowledge, job seekers need to be proactive and flexible in identifying career opportunities. 
Zaharim et al. (2009) defined employability skills as those needed to obtain and keep a fulfilling job, as well as the ability to teach and transfer their knowledge within the work environment. The OECD commissioned studies on employability from 2016 and 2015 (OECD, 2016a; OECD, 2016b; OECD, 2015) pointed out that the desired skills for employability involve good text interpretation, mathematical knowledge and other soft skills. The study highlights information management and problem-solving as key factors for employability. These include the ability to evaluate, access, communicate and analyze information-both interpreting text-based information and handling mathematical data (OECD, 2015).

A study by the Australian Employment Agency, the Monarch Institute (Monarch Institute, 2015), found that $85 \%$ of the desirable skills for employability are related to soft skills, while $15 \%$ are technical skills, highlighting the importance of the need to teach and highlight soft skills during the academic period.

Studies show that Engineers should be responsible for appropriating new knowledge, expressing their ideas proactively, critically and independently. The studies also point out that already during university, Engineer students need to start developing the ability to provide original and creative solutions to real-life problems. Furthermore, working in teams, managing interdisciplinary groups, understanding society demands taking into perspective the ecological, ethical and political repercussions of their actions also arise (Klafke, 2005).

According to Caten et al. (2019), the importance of soft skills required for current and future Engineers exceeds the importance of the technical ones. Leadership, creativity, communication, management, professionalism, ethics, agility, resilience and flexibility are some examples of skills that go beyond the technical competence and which give professionals more ability to take ownership of their own career and deal with the current market's demands. As Compton (2008) has studied, the skills that will be required for post-university management and leadership positions are those that develop based on the Humanities and Social Sciences, such as: demonstrating passion and interest, taking on current roles and responsibilities that seek continuously opportunities for improvement; volunteering to get involved in other projects and working groups, developing the perspective of resolving organizational challenges; and self-assessment to learn from mistakes and cultivation with demonstration of value characteristics that promote trust.

Organizations have been looking for Engineers who not only have the technical knowledge, but also have the ability to bridge this knowledge with their employees and social needs. According to Ajit and Deshmukh (2013), a newly graduated engineer who joins an organization already faces the first challenge when having to prove the ability to fit to the company's culture well as being able to deliver performance according to the demands.

Other studies reinforce that employers hope to recruit engineers with soft skills. Firstly, they reflect a person's commitment to developing their professional future in line with personal values, professional aspirations and social pers- 
pective (Bates et al., 2019). Consequently, it reflects better performance in innovation, such as sustainable technological development and infrastructure, matching the society's expectations (Kulkarni et al., 2017).

To apply and practice knowledge effectively in the workplace, Engineers need to be endowed with soft skills, as companies increasingly require creative and innovative engineers, thus establishing competitive advantages for their companies (llamas et al., 2019).

While the current hiring trends for engineers suggest the need to emphasize soft skills, according to the report by major US companies-Q21: Partnership for 21st Century Learning-(Casner-Lotto \& Barrington, 2006), only a quarter of university fourth graders are perceived as excellent in many skills, including reading, math and sociability. The others are considered unprepared for written and communication, mathematics and reading.

All the above stated clearly shows a gap between Engineering education and job market expectations, reemphasizing the importance of the present study as a way to bring to light studies already developed on soft skills for Engineers.

\section{Methodology}

As the main objective of the present work is to gather studies already present in the current state-of-art, the chosen methodology was a Systematic Bibliographic Review (SBR). According to Conforto, Amaral, \& Silva (2011: p. 3), "Systematic literature review is a scientific method for searching and analyzing articles from a particular area of science".

\subsection{Selection Criteria}

Firstly, it is important to note that the SBR was based on articles published in journals, as the topic was more likely to have been approached in articles than in patents and other kinds of academic work.

For this method, the choice of key words was the first criteria used for selection of relevant work. As this study bases itself on two major nuclei, Engineering and Humanities, Human Sciences, Human Skills, Engineering Education and Engineering Degree were chosen as the relevant key words. From there, 20 combinations of keywords in English language were used.

\subsection{Data Bases}

The selection of Data Bases was based on those that showed greater proximity to the Research Area, These were the following: Science Direct, Web of Science and Scopus. Although the European Journal of Engineering Education (EJEE) is indexed on the Scopus science base, it was also used as an individual search reference because of its self-indexed scope.

Furthermore, Journal of Engineering Education (JEE) articles from 2006 to 2015 were also performed, as this is a journal with the highest impact factor-, 1.739-, within the area of Engineering Education, and is not indexed in the pre- 
viously mentioned Data Bases.

As some articles were indexed in more than one scientific Database, it was also necessary to remove duplicates. The number of articles gathered, according to the keywords, are shown in Table 1.

\subsection{Articles Selection}

After the first screening, the 2638 titles and abstracts were read to verify that they were indeed aligned with the topic Among these, 335 were within the scope of the study, in addition to the 9 articles selected from the JEE Journal.

Table 1. SBR summary with keywords targeting this study.

\begin{tabular}{cc}
\hline & Number of Articles \\
\hline Number of articles without filters & 3951 \\
Number of articles after filters & 2788 \\
Number of articles after duplicates removal & 2638 \\
\hline
\end{tabular}

Source: Own authorship (2019).

Finally, the pre-selected articles were of ordered in terms of relevance, through an algorithm known as Methodi Ordinatio (Pagani, Kovaleski, \& Resende, 2015). This ordering algorithm takes into account the number of Google Scholar citations, the impact factor and the year of publication as shown by Equation 1 coined by authors Pagani, Kovaleski and Resende (2015) in their study.

Equation 1

$$
\text { InOrdinatio }=(\mathrm{Fi} / 1000)+\alpha *[10-(\text { AnoPesq }- \text { AnoPub })]+\sum C_{i}
$$

Source: Pagani, Kovaleski \& Resende (2015)

where:

$$
\left\{\begin{array}{l}
i: \text { Impact Factor } \\
\text { AnoPesq : Year of Article Search } \\
\text { AnoPub : Article Publication Year } \\
C_{i}: \text { Number of citations in Google Scholar }
\end{array}\right.
$$

After submitting the 335 pre-selected articles to InOrdinatio, 58 articles, along with the 9 JEE Periodicals, were chosen to be critically read. All of the soft skills mentioned in the 58 articles were listed in the OECD reports (OECD, 2015; OECD, 2016a; OECD, 2016b) and in document P21 (Casner-Lotto \& Barrington, 2006).

\section{Results and Discussion}

The most relevant soft skills for Engineers according to the mentioned methodology are presented and discussed in this Section. These skills are grouped into six main groups, as a way to structure interrelated skills.

The discussion starts by highlighting the main pillars of the knowledge needed by an Engineer and how the main groups of soft skills support this knowledge. 


\subsection{Problem Solving and Critical Thinking}

Problem-solving can be considered the core soft skill expected from an Engineer. Figure 1 is adapted from, Thibault et al. (2002), in which the author visually represents Planning and Problem Solving as the two milestones in Engineering career. From there, the author presents different skills and, according to which triangle they fall into predominantly, it is possible to see to which milestone they relate at most.

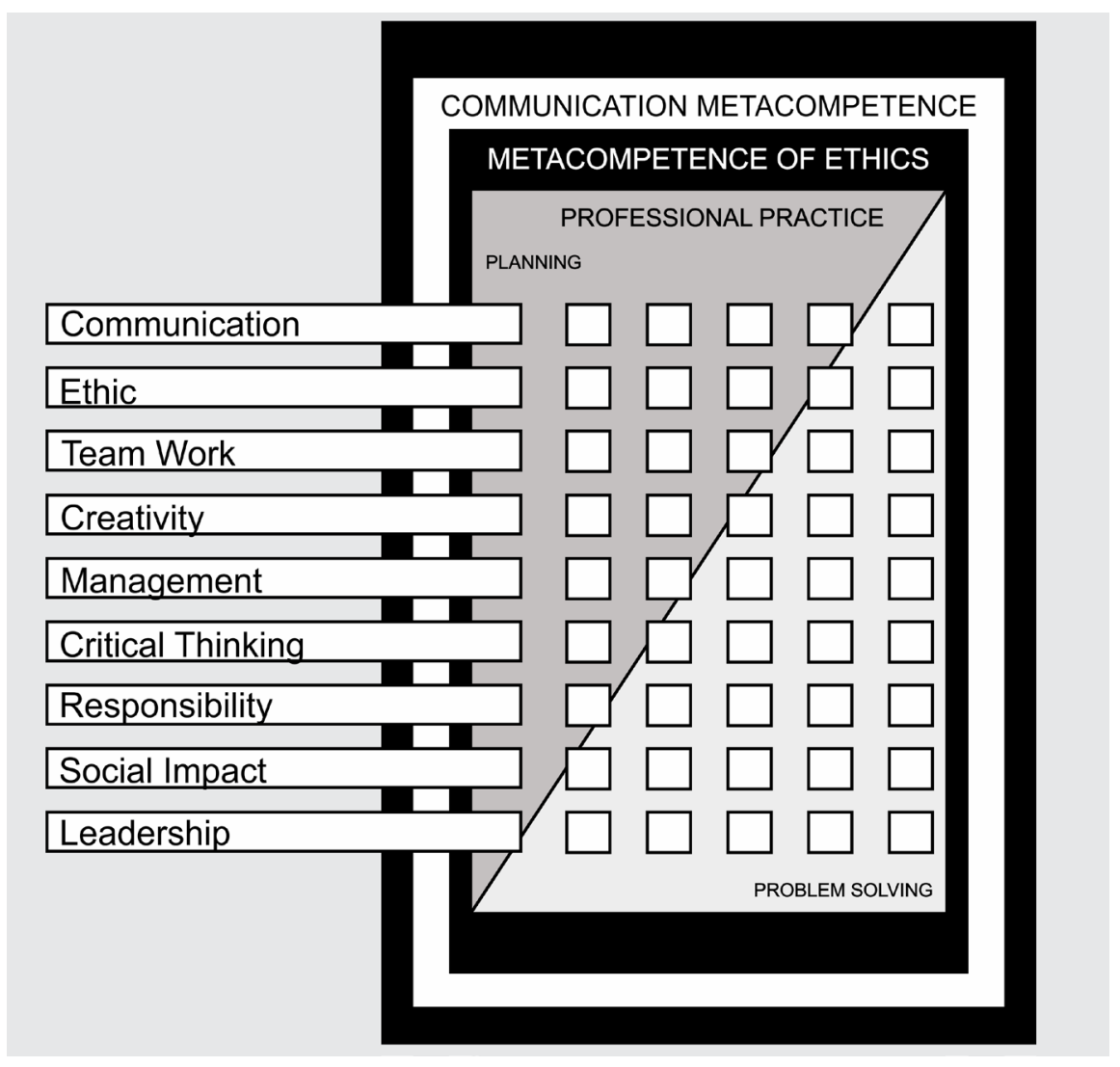

Figure 1. Interaction in engineering practice between science \& technology skills and soft skills. Source: Adapted from Thibault et al. (2002).

Firstly, it is important to understand that the nature of Engineer career demands the ability to solve problems and, more than that, both the problems and the solutions need to be connected to the society's needs. That is why Problem Solving is presented in this study as the first group of soft skills important for an Engineer.

Downey et al. (2006) and Jesiek, Borrego, Beddoes (2010) define the Engineering work as activities that demand the interpretation of technological problems that need to be solved.

Therefore, all the other soft skills needed for an Engineer are those which, directly or indirectly, help and support them with the Problem-solving.

The first skill which directly relates to Problem-solving is Critical Thinking, as it could be considered one of the main pillars to develop problem solving capa- 
bility. In fact, the item "Critical Thinking", shown in Figure 1, falls predominantly in the light gray region belonging to "Problem Solving".

Critical thinking is the ability to analyze a situation through different perspectives, taking into account minimum time waste and, cost-savings inside a globally interconnected economy (Meireles \& Bonifácio, 2015; Barrera, 2017).

The relevance of "Critical Thinking" in the professional construction of Engineering has been discussed as early as 1990. O'Neal (1990) defines "Critical Thinking" as the aptitude to make judgments, based on appropriate questioning, including questioning of authority as well as the competence to act independently and wisely. The faculty of "Critical Thinking" provides greater assertiveness in decision making.

That is the reason why Engineering courses should encourage their students to discuss past or present standards and to question the status quo when they feel appropriate.

\subsection{Communication}

The second group of competences found to be relevant for Engineers is Communication. According to the OECD (2015), communication in its entirety is achieved with effective and accurate writing, interpretation and speaking.

The ability to correctly search for data and to interpret information, avoiding bias, is also interrelated to the already mentioned critical thinking and, consequently, problem solving. Second, the capacity of presenting this information in an easy and clear manner also helps others with problem solving and information analysis. That is why these are so important for Engineers.

\subsubsection{Verbal and Written Communication}

Studies suggest a great link between Engineering failures and lack or inefficient communication. The areas usually associated with humanities could be better approached in Engineer's courses to help decrease communication errors (May \& Deckker, 2009).

In Engineering, "Verbal Communication" facilitates dialogue and helps develop arguments to state or defend an idea. It also helps when orientating new collaborators, communication between colleagues and the effective communication of project concepts and scopes to clients and/or managers.

Fletcher, Sharif and Haw (2016), on the other hand, focus on 'Written Communication'. In their research, they use as an example the Chemical Engineering students, for which the writing ability was said to be "unsatisfactory". As a consequence, the authors proposed a writing course as a way to strengthen the communication ability.

The P21 report (Casner-Lotto \& Barrington, 2006) also highlights speaking a foreign language as an important employability factor, when he says that those able to communicate in another language are way ahead in business than those limited to their native language.

The importance of communication is strongly related to the characteristics of 
the Engineering profession. As Engineers are constantly in contact with other people, such as clients, vendors, consumers, clients and even authorities, as well as other colleagues from different fields, the ability to express in an efficient and clear way is key. The knowledge in a foreign language is obviously an asset for those working in a foreign environment, either a foreign country or dealing with costumer from across the globe.

\subsubsection{Reading}

As expected, the writing and verbal communication are related to the effective reading ability, which is also an ability required different job positions. Figure 2 shows the average Engineering salaries in different countries, according to different requisites, surveyed by the OECD (2016b).

An analysis of Figure 2 clearly shows that, in most of the countries, the best-paid jobs will require reading at work. Contemporary society requires not only a professional capable of communicating through different channels, but especially a professional able to interpret data and information. Engineers are frequently dealing with data. The common sense tends to associate Engineers with mathematical or modelled data, which is just half of the picture. Engineering is a broad and very interdisciplinary profession.

As many Engineers deal with projects, they have to go through safety and environmental regulations, local laws and many other requirements out of their main domain of study. Although they are not specialists, they still need to be able to read documents and regulations and interpret this information in an appropriate manner.

\subsubsection{Active Listening}

"Active Listening", considered in the list of soft skills as necessary for the engineer, coined by the OECD (2015) for "Attentive Listening", was categorized as

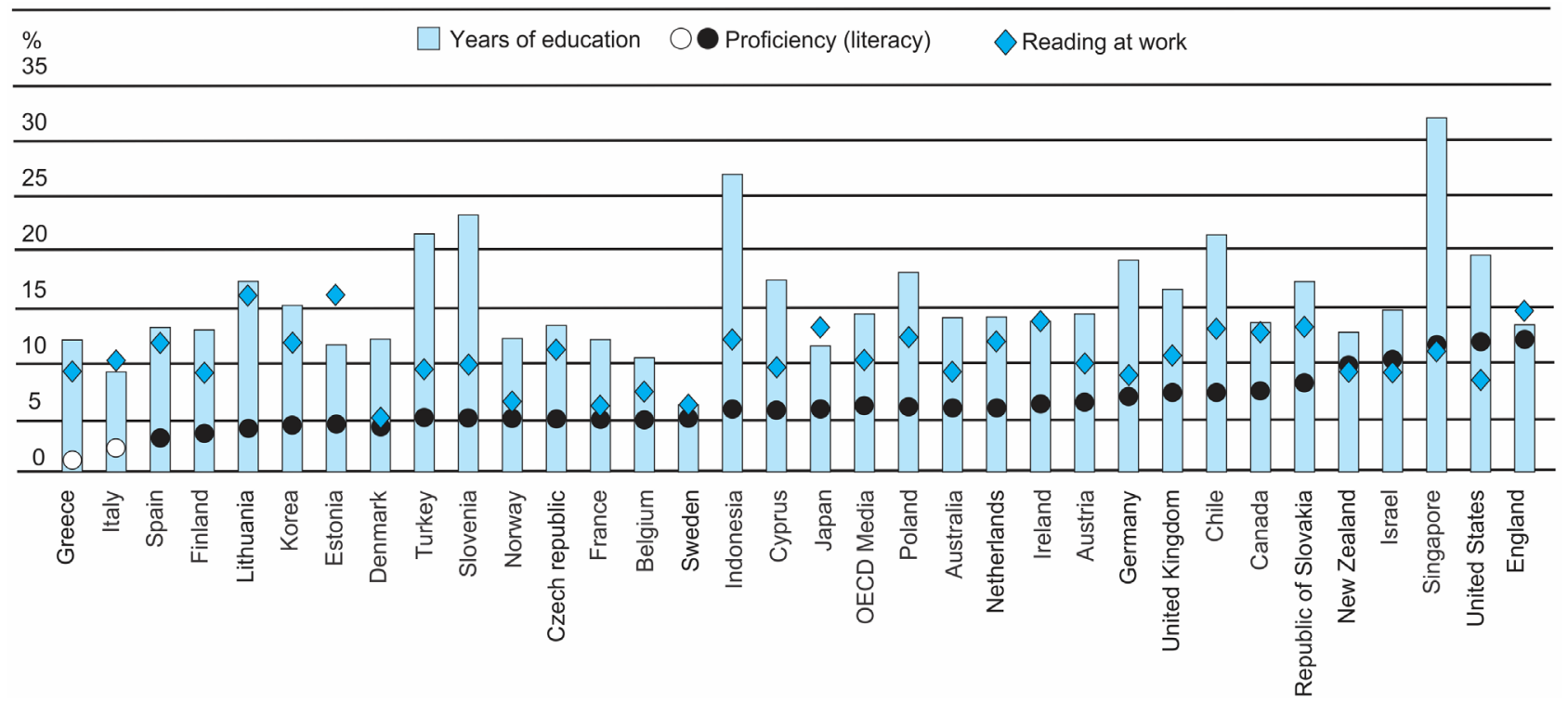

Figure 2. Impact on education, literacy and use of reading at work according to salaries. Source: OECD (2016b). 
"very important" for the exchange of views between people. Andersen and Hansen (2002), call "Empathic Listening" the ability to listen attentively and communicate unambiguously, thus facilitating the resolution of engineering problems.

The Active Listening still falls back into the interdisciplinary of the profession and the necessity to transition into different fields. As an Engineer comes across some field they are not familiar with, they need to communicate to specialists in that field and, in this case, the Active Listening will be the main skill required inside the communication group of skills.

\subsection{Team Work}

As already mentioned, the interdisciplinary nature of an Engineering work brings to light the importance of interpersonal skills. Some of these interpersonal skills are implicit in some of the previously mentioned features, such as verbal communication, active listening and even in critical thinking, for example. However, some skills explicitly account for the competence to relate to others. This group of skills is presented here as Teamwork.

Colby and Sullivan (2008) highlight the Team Work skills for high quality Engineering work. Andersen and Hansen (2002) are also emphatic on its importance for Engineers, mentioning it as a fundament for their career, both domestically or internationally.

Downey et al. (2006) and Jesiek, Borrego, \& Beddoes (2010), in the same work where they define an Engineer as a Problem-solver, also highlight that for the problem-solving, the negotiation and discussion of potential solutions, both among Engineers peers and non-Engineers-clients, authorities, colleagues, experts-is necessary. Also according to Casner-Lotto \& Barrington (2006), the greater the improvement of information technologies used by companies, the more diverse and skilled their workforce, as they solve problems based on very different points of view, expertise and experience.

Other important characteristics inside Team Work are Optimism, Common Sense, Empathy, Collaborative Spirit and Negotiating Skills. They also include situational awareness to take the decision that produces the best outcome for everyone involved (Kamin, 2013).

\subsubsection{Multiculturalism}

Many people associate multiculturalism to living in a completely different culture, usually another country. However, as each human is an individual and has its own values, multiculturalism refers more broadly to the respect of other's individuality, including choices, values, believes. The employability studies contained in the P21 report (Casner-Lotto \& Barrington, 2006) and the OECD $(2015,2016 a, 2016 b)$ point to the need to learn to work in diversity.

For Engineering, the importance of diversity, both in the academic environment or in the job market, is also noted by scientists and scholars in the field. Li and $\mathrm{Fu}$ (2012) point out that cultural and ethnic diversity must be addressed in 
all educational projects in the area of Engineering.

\subsubsection{Network}

The Contact Network also stands as a valuable factor for employability. It is defined as one's ability to form a web of meaningful contacts. The Contact Network is internationally recognized by the word Networking (Perkins, 2001). An extended network also expands the employability of Engineers. According to Becker (2006), positions such as sales and marketing require the bachelor of engineering to sharpen their social skills in order to build a solid professional contact network as an important resource for career success. Although they might seem unrelated to Engineering, many Engineers today are employed in sales positions and sales and marketing competences can be applicable to anyone's daily lives and are not limited to a specific career.

\subsubsection{Leadership}

Another very remarkable attitude or competence in the Team Work group is Leadership. The surveys conducted by P21 (Casner-Lotto \& Barrington, 2006) and OECD (2016a, 2016b) reports recognize that the adoption of Leadership and Management practices in the workplace creates opportunities for skills and productivity boosts

Leadership is not only related to managing others, but also to be able to lead a specific project, to take ownership and responsibility on one's own actions and to be able to stand for what one considers to be correct. Still related to the problem-solving, Engineers need to be proactive to recognize a problem and take leadership when proposing a solution within a group.

Other studies in the field have shown that people with comparable intelligence were judged differently based on their leadership attitudes (O'Neal, 1990). More recent studies, Passino (2009), Kasamoto (2000) and Lyman (2002), advocate the inclusion of leadership subjects within the curricula of all Engineering.

\subsection{Ethical Perspective: Ethics per se, Professionalism and Social Responsibility}

In this topic, "Ethics per se", "Professionalism" and "Social Responsibility" were combined into a major called "Ethical Perspective", as they all relate to ethics and its consequences when taking action and decision making.

An ethical person is said to be one who has a good character. Defined in report P21 (Casner-Lotto \& Barrington, 2006) and by the $\operatorname{OECD}(2015,2016 \mathrm{a}$, 2016b), ethics is the demonstration of personal accountability and effective work habits (i.e., punctuality, productive work with others, time and workload management). It is also a desired virtue in human relationships According to Chauí (2011) and Cotrim (2002), ethics, greater than common sense and morality a universal principle and has to accompany an individual throughout their lives.

As Engineers solve problems, they make decisions and these decisions have to be taken considering their potential consequences. They need to be able to have a broader view on how their decisions can have an impact on the society. 
Rugarcia et al. (2005) and Lathem, Neumann, \& Hayden (2011) stated Engineers often make decisions disregarding the moral, ethical and social consequences of their with the mistaken belief that the potential damages brought by their decisions are the responsibility of others.

The development of ethics in Engineering students develops a future professional that knows the importance of considering the responsibility for their actions and decisions. These professionals will have more assertiveness in their decision making process (Beever \& Brightman, 2016). Jones, Michelfelder, \& Nair (2017) point out that engineers must direct their actions ethically to the social, economic and ecological needs, which represents their "Social Responsibility".

A survey of the corporate world (OECD, 2015; Casner-Lotto \& Barrington, 2006) certifies that $80.3 \%$ of respondent employers classified working with ethics as "very important".

According to Rondon (2016), professionalism is diametrically associated with attributes such as good character, seriousness, competence and responsibility, permeating the field of ethics. In the survey of the P21 report (Casner-Lotto \& Barrington, 2006) $80.3 \%$ of the interviewed employers, also claimed to be "very important" for job seekers to have a personal responsibility, "Professionalism" and commitment to the work. For McAloone (2007), an Engineer must articulate their performance with "Professionalism" in order to have the ability to operate in global companies respecting its place and culture.

\subsection{Emotional Intelligence: Emotions Control, Motivation, Lifelong Learning and Self Direction}

Emotional Intelligence stands for one's capability of perceiving, understanding and controlling their own emotions (Petrides et al., 2016). This is the reason why Emotions Control, Motivation, Lifelong Learning and Self-Direction are said to be part of the Emotional Intelligence.

With the cultural diversity of work environments, it is necessary to consider the most diverse points of view that can end up impacting people's emotions. Emotional control, focus on achieving one's goals, an interest in continuing one's lifelong empowerment, and self-direction are characteristics that belong to IE and are also desirable for maintaining the harmony of the engineer's work environment.

The report on Competencies for Social Progress (OECD, 2015) reports that the Dominican Republic already implements a program called Youth and Employment, which provides classroom training for future workers. The program englobes self-esteem promotion, work motivation and communication skills. This type of initiative ensures that the content of vocational training is facilitated according to the demands of employers.

Already in 2004, Hansen suggested that companies wishing to improve their Engineers skills should provide favorable environments for their development throughout their career path. According to him, Lifelong Learning through further education should be seen as part of this development. Jiusto and Dibiasio 
(2006) emphasize that Lifelong Learning is achieved through continuous personal development.

The resulting reports from a research on employability around the world (Casner-Lotto \& Barrington, 2006; OECD, 2015, 2016a) also bring up Self-Direction as a characteristic linked to Lifelong Learning and highlight the importance of one's own initiative for staying up-to-date through studying and focusing on developing their strengths and overcoming their weaknesses.

\subsection{Creative Thinking: Creativity and Innovation}

Creativity is the ability of providing and applying new ideas into Problem Solving (Hasanah \& Surya, 2017). As a fundamental element of Engineering, Creativity facilitates the generation of effective and innovative solutions to various problems (Cropley, 2016).

Among the many skills listed as important for employability in the 21 st century, Creativity has both cognitive and soft skills elements. This competence is also called Divergent Thinking, as it involves the production of content not only innovative, original and unexpected, but bold, useful and adapted to a given task (Casner-Lotto \& Barrington, 2006). In its study on employability, the OECD points out that creative people tend to be more open to new experiences, more imaginative, more impulsive and more outgoing (OECD, 2015).

Engineering science as well as Management and Leadership skills are often referred to as sources of innovation within companies. However, according to the results of studies by Schneider, Günther, \& Brandenburg (2010) and Jesiek, Borrego, \& Beddoes (2010), a large portion of technically qualified employees is not sufficient for a company to be innovative, and does not imperatively make these employees creative and proactive.

Differently than most people think, Creativity is not an inspiration, nor is it a gift. It is the result of a structured path of thinking, which also requires enough background and repertory to occur. Inside the Engineering field, Creativity is achieved through constant personal improvement and through keeping up-to-date with the most current technologies

\subsection{Compilation and Analysis of Results}

As a result of the conducted SBR for this study, the main soft skills discussed were compiled in Figure 3, through a graphical representation oriented by related areas. This circle represents all the skills needed for an Engineer to succeed in their profession, considering success not only as economical terms, but also considering their role and responsibility to solve society's problems and needs. According to SBR, the most frequently encountered soft skills are those of the outer circle of the figure that were, as proposed in this research, systematized into the six categories described in the results of this study and ordered in the inner circle. A successful Engineer can bridge soft and technical skills (Pereira \& Costa, 2017). 


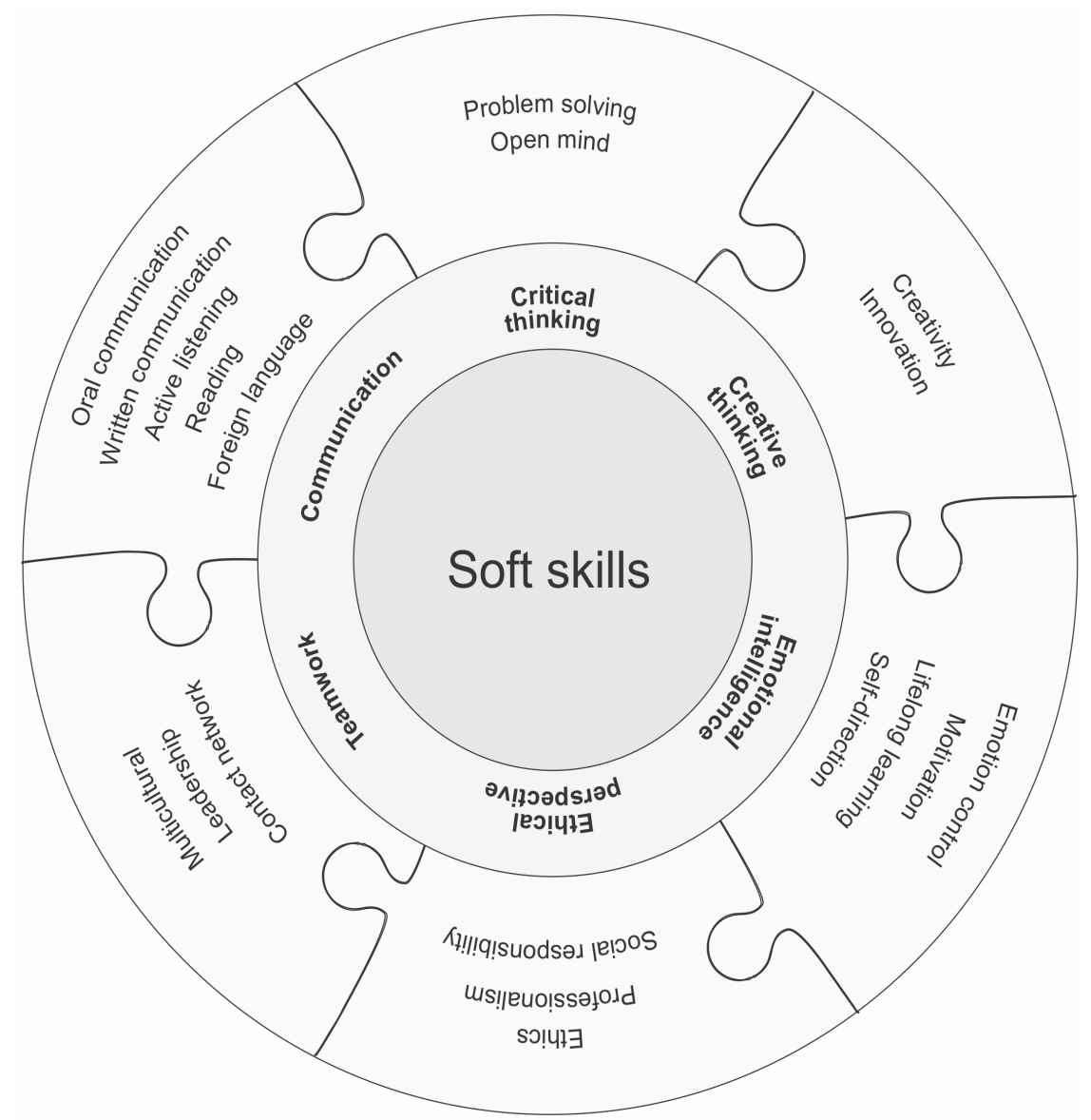

Figure 3. Compilation of the important soft skills for engineers grouped by their core competences. Source: Own authorship (2020).

All the presented studies converge to the concept of an Engineering education which not only requires the students to understand traditional Engineering fundamentals such as Mechanics, Dynamics, Mathematics and Technology, but also to develop the so-called situational skills. These account for skills needed to handle real situations and are englobed in the six categories of soft skills into which the present work is based.

The society expects Engineering graduates to be able to absorb and develop new technologies by acting critically, boldly and creatively when identifying and solving problems. Therefore, they need to be able to consider the political, social, environmental and cultural aspects, always in an ethical manner.

\section{Final Considerations}

As initially proposed, this structured the social and emotional skills (soft skills) in the lenses of Engineering employability, highlighting the relationship between each skill and an Engineer work.

Through a high-quality SBR, it was found out that the most important soft skills for Engineers can be categorized into six main groups: Problem Solving, Communication, Team Work, Ethical Perspective, Emotional Intelligence and 
Creative Thinking. All these are composed of different soft skills, but summarize in a structured way the core competencies an Engineer has to have, always keeping in mind the problem-solving nature of the profession.

In order to be aligned with the current demands of the market and the society, the Engineering education must go beyond its technical and theoretical pillars, as there is no Problem Solving capability without all the other soft skills presented during this work.

Undoubtedly, there is much more to be reflected and discussed regarding the existing gap between Engineering Education, Job Market and Society's needs. The main aim of this article is neither to answer this question, nor to exhaustively present all the possible solutions. The intent is to raise this as an important topic for the Scientific Community and promote reflection not only for Companies and Education Professionals, but also on the current and future Engineers. After all, education has an impact on the acquisition of the required soft skills, but it is important not to forget the Life-Long Learning and Self-Direction mentioned as important soft skills. Both the university or trainings and the work environment need to give the Engineer the necessary tools for self-development and self-knowledge. However, it is up to the professional to use these tools to take ownership of their own career, working to be updated on technical knowledge and on development of weaknesses and strengths.

\section{Conflicts of Interest}

The authors declare no conflicts of interest regarding the publication of this paper.

\section{References}

Ajit, V., \& Deshmukh, P. B. (2013). Factors Impacting Employability Skills of Engineers. International Journal of Science and Research, 2, 30-32.

Andersen, A., \& Hansen, J. (2002). Engineers of Tomorrow and beyond Knowledge, Insight and Skills Needed to Work across Borders. Age, 7, 1.

Barrera, A. (2017). Social Economy and Critical Thinking. Apontes for the Analysis of the Current Scenario. Labor and Sociedad, 29, 517-535.

Bates, G., Rixon, A., Carbone, A., \& Pilgrim, C. (2019). Beyond Employability Skills: Developing Professional Purpose. Journal of Teaching and Learning for Graduate Employability, 10, 7-26. https://doi.org/10.21153/jtlge2019vol10no1art794

Becker, F. S. (2006). Globalization, Curricula Reform and the Consequences for Engineers Working in an International Company. European Journal of Engineering Education, 31, 261-272. https://doi.org/10.1080/03043790600644749

Beever, J., \& Brightman, A. O. (2016). Reflexive Principlism as an Effective Approach for Developing Ethical Reasoning in Engineering. Science and Engineering Ethics, 22, 275-291. https://doi.org/10.1007/s11948-015-9633-5

Casner-Lotto, J., \& Barrington, L. (2006). Are They Really Ready to Work? Employers' Perspectives on the Basic Knowledge and Applied Skills of New Entrants to the 21st Century US Workforce.

Caten, C. S., Silva, D. S., Aguiar, R. B., Filho, L. C. P. S., \& Huerta, J. M. P. (2019). Re- 
shaping Engineering Learning to Promote Innovative Entrepreneurial Behavior. Brazilian Journal of Operations \& Production Management, 16, 141-148. https://doi.org/10.14488/BJOPM.2019.v16.n1.a13

Chauí, M. (2011). Invitation to Philosophy(14th ed.). Sao Paulo: Attica.

Colby, A., \& Sullivan, W. M. (2008). Ethics Teaching in Undergraduate Engineering Education. Journal of Engineering Education, 97, 327. https://doi.org/10.1002/j.2168-9830.2008.tb00982.x

Compton, D. S. (2008). High Reliability Leadership: Developing Executive Leaders for High Reliability Organizations. 376f. Thesis (Doctorate), Ann Arbor: The Faculty of the School of Business of the George Washington University.

Conforto, E. C., Amaral, D. C., \& Silva, S. L. (2011). Script for Systematic Literature Review: Application in Product Development and Project Management. In 8th Brazilian Congress of Product Development Management (CBGDP) (pp. 1-12). Porto Alegre: FAPESP.

Cotrim, G. (2002). Fundamentals of Philosophy: History and Major Themes (15th ed.). Sao Paulo: Saraiva.

Cropley, D. H. (2016). Creativity in Engineering. In Multidisciplinary Contributions to the Science of Creative Thinking (pp. 155-173). Singapore: Springer. https://doi.org/10.1007/978-981-287-618-8_10

Downey, G. L., Lucena, J., Moskal, B. M., Parkhurst, R., Bigley, T., Hays, C., Jesiek, B. K., Kelly, L., Miller, J., Ruff, S., Lehr, J. L., \& Belo, A. N. (2006). The Globally Competent Engineer: Working Effectively with People Who Define Problems Differently. Journal of Engineering Education, 95, 107-122. https://doi.org/10.1002/j.2168-9830.2006.tb00883.x

Fletcher, A. J., Sharif, A. W. A., \& Haw, M. D. (2016). Using the Perceptions of Chemical Engineering Students and Graduates to Develop Employability Skills. Education for Chemical Engineers, 18, 11-25.

Hansen, S. (2004). The Supervisor in the Project-Organized Group Work Should Participate in Developing the Students' Project Competencies. European Journal of Engineering Education, 29, 451-459. https://doi.org/10.1080/03043790310001658596

Hasanah, M., \& Surya, E. (2017). Differences in the Abilities of Creative Thinking and Problem Solving of Students in Mathematics by Using Cooperative Learning and Learning of Problem Solving. International Journal of Sciences: Basic and Applied Research (IJSBAR), 34, 286-299.

Itani, M., \& Srour, I. (2015). Engineering Students' Perceptions of Soft Skills, Industry Expectations, and Career Aspirations. Journal of Professional Issues in Engineering Education and Practice, 142, Article ID: 04015005. https://doi.org/10.1061/(ASCE)EI.1943-5541.0000247

Jesiek, B. K., Borrego, M., \& Beddoes, K. (2010). Advancing Global Capacity for Engineering Education Research (AGCEER): Relating Research to Practice, Policy, and Industry. Journal of Engineering Education, 99, 107-119. https://doi.org/10.1002/j.2168-9830.2010.tb01048.x

Jiusto, S., \& Dibiasio, D. (2006). Experiential Learning Environments: Do They Prepare Our Students to Be Self Directed, Life Long Learners? Journal of Engineering Education, 95, 195-204. https://doi.org/10.1002/j.2168-9830.2006.tb00892.x

Jones, S. A., Michelfelder, D., \& Nair, I. (2017). Engineering Managers and Sustainable Systems: The Need for and Challenges of Using an Ethical Framework for Transformative Leadership. Journal of Cleaner Production, 140, 205-212.

https://doi.org/10.1016/j.jclepro.2015.02.009 
Kamin, M. (2013). Soft Skills Revolution: A Guide for Connecting with Compassion for Trainers, Teams, and Leaders. Hoboken, NJ: John Wiley \& Sons.

Kasamoto, N. H. (2000). A Course on Engineering Leadership. Journal of Professional Issues in Engineering Education and Practice, 126, 134-135. https://doi.org/10.1061/(ASCE)1052-3928(2000)126:3(134)

Klafke, P. A. (2005). Bases for Continued Training of Product Development Engineer Aiming at Technological Innovation. 175 f. Dissertation (Master), Santa Maria, CA: Postgraduate Program in Production Engineering, Federal University of Santa Maria.

Koen, P. A., \& Kohli, P. (1998). ABET 2000: What Are the Most Important Criteria to the Supervisors of New Engineering Undergraduates. Age, 3, 2.

Kulkarni, V. A., Bewoor, A. K., Malathi, P., \& Balapgol, B. S. (2017). Employability Skill Matrix for Engineering Graduates of Tier-II Institutes.

Lathem, S. A., Neumann, M. D., \& Hayden, N. (2011). The Socially Responsible Engineer: Assessing Student Attitudes of Roles and Responsibilities. Journal of Engineering Education, 100, 444-474. https://doi.org/10.1002/j.2168-9830.2011.tb00022.x

Li, J., \& Fu, S. (2012). A Systematic Approach to Engineering Ethics Education. Science and Engineering Ethics, 18, 339-349. https://doi.org/10.1007/s11948-010-9249-8

Llamas, B., Gracia, M. D. S., Mazadiego, L. F., Pous, J., \& Alonso, J. (2019). Assessing Transversal Competences as Decisive for Project Management. Thinking Skills and Creativity, 31, 125-137. https://doi.org/10.1016/j.tsc.2018.11.009

Lyman, F. A. (2002). Humanities and Social Sciences in Engineering Education-Postwar to Postmodern and Beyond. In Technology and Society, Proceedings. International Symposium on IEEE (pp. 73-81). New York: Institute of Electrical and Electronics Engineers.

Marrocu, E., \& Paci, R. (2012). Education or Creativity: What Matters Most for Economic Performance? Economic Geography, 88, 369-401. https://doi.org/10.1111/j.1944-8287.2012.01161.x

May, I. L., \& Deckker, E. (2009). Reducing the Risk of Failure by Better Training and Education. Engineering Failure Analysis, 16, 1153-1162. https://doi.org/10.1016/j.engfailanal.2008.07.006

Mcaloone, T. C. (2007). A Competence-Based Approach to Sustainable Innovation Teaching: Experiences within a New Engineering Program. Journal of Mechanical Design, 129, 769-778. https://doi.org/10.1115/1.2723806

Meireles, M. C., \& Bonifácio, B. (2015). Use of Agile Methods and Problem-Based Learning in Software Engineering Teaching: An Experience Report. In 8th Brazilian Product Development Management Congress (pp. 180-189). Cairó: IFRN.

Monarch Institute (2015). http://www.monarch.edu.au

O'neal, J. B. (1990). The Humanities and Their Effect on Engineering Education. IEEE Communications Magazine, 28, 30-35. https://doi.org/10.1109/35.61718

OECD (2015). Skills for Social Progress: The Power of Social and Emotional Skills. OECD Skills Studies. Paris: OECD Publishing. https://doi.org/10.1787/9789264226159-en

OECD (2016a). Skills Matter: Further Results from the Survey of Adult Skills. OECD Skills Studies. Paris: OECD Publishing. https://doi.org/10.1787/9789264258051-en

OECD (2016b). The Survey of Adult Skills: Reader's Companion (2nd ed.). OECD Skills Studies. Paris: OECD Publishing. https://doi.org/10.1787/9789264258075-en

Pagani, R. N., Kovaleski, J. L., \& Resende, L. M. (2015). MethodiOrdinatio: A Proposed Methodology to Select and Rank Relevant Scientific Papers Encompassing the Impact 
Factor, Number of Citation, and Year of Publication. Scientometrics, 105, 2109-2135. https://doi.org/10.1007/s11192-015-1744-x

Passino, K. M. (2009). Educating the Humanitarian Engineer. Science and Engineering Ethics, 15, 577. https://doi.org/10.1007/s11948-009-9184-8

Pereira, O. P., \& Costa, C. A. A. T. (2017). The Importance of Soft Skills in the University Academic Curriculum: The Perceptions of the Students in the New Society of Knowledge. International Journal of Business and Social Research, 7, 25-34. https://doi.org/10.18533/ijbsr.v7i6.1052

Perkins, C. E. (2001). Ad Hoc Networking. Reading, PA: Addison-Wesley.

Petrides, K. V., Mikolajczak, M., Mavroveli, S., Sanchez Ruiz, M. J., Furnham, A., \& Pérez González, J. C. (2016). Developments in Trait Emotional Intelligence Research. Emotion Review, 8, 335-341. https://doi.org/10.1177/1754073916650493

Ríos Carmenado, I. L., López, F. R., \& García, C. P. (2015). Promoting Professional Project Management Skills in Engineering Higher Education: Project-Based Learning (PBL) Strategy. International Journal of Engineering Education, 31, 1-15.

Rondon, R. (2016). Higher Education and Work: The "One Dimensionality" of Discourse. Present Time Bulletin No. 11.

Rugarcia, A., Felder, R. M., Woods, D. R., \& Stice, J. E. (2005). The Future of Engineering Education I. A Vision for a New Century. Chemical Engineering Education, 34, 16-25.

Schneider, L., Günther, J., \& Brandenburg, B. (2010). Innovation and Skills from a Sectoral Perspective: A Linked Employer-Employee Analysis. Economics of Innovation and New Technology, 19, 185-202. https://doi.org/10.1080/10438590902872887

Silva, D. A., Machado, P. L., Coelho, V. C. G., Barbosa, R. V., Mendonça, F. L. L., Santos, D. P., \& Júnior, R. T. S. (2019). Production of Employability Indicators Based on Big Data Mining Techniques and Business Intelligence. Social Inclusion, 12, 141-155. http://revista.ibict.br/inclusao/article/view/4670

Thibault, R. A., Hivon, R., Lheureux, D., \& Boutin, N. (2002). The Development of the Competencies Linked to the Human Dimension of Engineering. Age, 7, 1.

Vasconcelos, J. A. (2018). Reflections. Philosophy and Daily Life. Sao Paulo: Publisher SM.

Vasko, T. J., Al-Masoud, N., \& Baumann, P. F. (2011). Assessment of Soft-Skills Program Learning Outcomes Using Engineering Courses. In Proceedings of the American Society for Engineering Education Annual Conference. Washington DC: American Society for Engineering Education.

Veiga, S. L. S. G. E. (2017). The Soft Skills of College Finalists: Aligning or Gaping with the Job Market? 148f. Doctoral Thesis, Lisbon.

Zaharim, A., Yusoff, Y. M., Zaidi, M., \& Mohamed, A. (2009). Engineering Employability Skills Required by Employers in Asia. In Proceedings of the 6th WSEAS International Conference on Engineering Education (pp. 195-201). Rodos Island: WSEAS. 